\title{
Rebooting Biculturalism in Education in Aotearoa-New Zealand
}

New Zealand Journal of Teachers' Work, Volume 15, Issue 1, 20-23, 2018

\author{
GEORGINA STEWART \\ School of Education \\ Auckland University of Technology
}

In a recent article published in this journal, Christine Jenkin (2017) discusses the meaning of 'biculturalism' and its implications for practice in early childhood education. Jenkin must be commended, first, for recognising that biculturalism is an influential yet misunderstood concept in education policy in Aotearoa-New Zealand, and second, for her personal commitment to biculturalism, demonstrated by her declaration that, despite being (as she puts it) a Pākehā researcher with a Pākehā-centric worldview, she is "motivated to provide a counter to the dominant Pākehā socio-economic and political perspective" ( $p$. 9). This opinion piece is motivated by my own personal commitment to biculturalism as viewed from a 'Māori-centric' perspective-and cognisant that profiting from the benefits of biculturalism will depend on better general levels of understanding amongst our Pākehā allies in education practice and research (Stewart, 2018).

This opinion piece responds to Jenkin's article, identifying some points of divergence, and offering alternative conclusions. My research approach is a form of critical discourse analysis or CDA (Locke, 2004) that locates itself in an indigenous Māori worldview, under the umbrella of the wider intellectual project of Kaupapa Māori (Hoskins \& Jones, 2017; Stewart, 2017b). Below, I argue for a radical form of biculturalism, as a profoundly educational concept for Aotearoa-New Zealand. The term from the title 'rebooting biculturalism' captures the aspiration of this opinion piece to catalyse more widespread and fruitful discussions.

In her article, Jenkin (2017) canvasses a range of local definitions of biculturalism and related terms, for example, a "bicultural curriculum, namely one honouring an equal relationship between Māori and non-Māori" (p. 8); "bicultural practice' [which] refers to Māori and Pākehā working in parallel" ( $p$. 8); and biculturalism itself as "a partnership between Māori and the Crown" ( $p$. 10). An 'official' definition of biculturalism for early childhood education states that it is:

a concept that implies the interactions, relationships, and sharing of understandings, practices, and beliefs between two cultures; in New Zealand, the term generally refers to Māori and non-Māori. (Ministry of Education, 1998, p. 86) 
Jenkin (2017) points out that many definitions of biculturalism, including many of those found in international literature, are inadequate because they overlook "the power relations inherent in biculturalism" (p. 10). She also notes a general confusion felt by early childhood teachers about the role of biculturalism in their practice, in particular in comparison with multiculturalism. So she suggests using the term 'Tiriti-based' instead, but this move simply side-steps the problem of lack of understanding of biculturalism, whilst also possibly generating further problems of understanding related to the contested role of the Treaty of Waitangi in society. Lack of understanding of what is at stake in bicultural education cannot be overcome by swapping terms around. In any case, terms such as 'Tiriti-based' act as mere proxies for larger underlying concepts such as biculturalism in education discourse. So I disagree with Jenkin's assessment of the use of 'Tiriti-based' as better than 'bicultural.' Instead, I argue for rehabilitating or rebooting the concept of biculturalism, which in its radical form has the capacity to act as an educational concept for society, and for the education system.

Looking more widely at the problem of definitions in the bicultural education literature, there is little or no effective difference operating between the categories of biculturalism, cross-culturalism, interculturalism, etc. Since all these terms are open to debate, it makes little sense to argue their relative merits or try to find the 'right' term to use. Lack of understanding in a field of practice such as early childhood education cannot be overcome by a new term or a new policy document. Many of the literature debates about the role and effect of addressing cultural diversity in education are straw-man: either-or arguments between reified binaries. Debate over the relative merits of biculturalism or multiculturalism, for example, does nothing for the members of social groups who are traditionally disadvantaged in education.

Biculturalism is a relationship in which the intellectual and sociopolitical histories of two peoples are intertwined over many generations. As such, biculturalism takes a unique form in each social context. Thus I argue that it is not possible to learn much from the international literature about biculturalism in Aotearoa-New Zealand, where the Māori-Pākehā relationship is primary (Hoskins, 2012). Jenkin (2017) starts from an important premise, namely that there is a general level of confusion and lack of understanding about biculturalism amongst teachers (not only in early childhood but also in schools and tertiary). It is therefore surprising that she uses a teacher survey as a source of data for exploring the meaning of biculturalism. This research approach seems to gloss over the difference between the range of meanings of a complex concept such as biculturalism, and the range of teacher understandings of that concept.

Biculturalism is an important topic for teachers in Aotearoa-New Zealand, who are under increasing pressure to take personal responsibility for reducing disparities in Māori educational outcomes. Yet expecting to find good or even adequate definitions of biculturalism in education policy suggests an uncritical belief in the transparency and fairness of the policy process, which is unwarranted (Olssen, Codd, \& O'Neill, 2005). The whole point of policy is to manage socio-economic relations, and policy text is, by definition, de-politicised. In short, many of the data sources Jenkin (2017) draws on have limitations for answering her question. In my view, definitions of biculturalism could be more 
usefully investigated using secondary sources of data found in the rich research archives of Māori education.

In recent work I have been exploring the effect of Pākehā misunderstanding of Māori views through the archives (Stewart, 2017a, 2017c; Stewart \& Dale, 2016). Māori have had no choice but to be bicultural, reflecting the general rule that only members of the dominant group can ignore ethnicity in a multicultural society. Biculturalism brings us face-to-face with incommensurable difference and the theoretical notion of the Other: biculturalism by its nature is unsettling and at times uncomfortable (Stewart, 2018). I liken the relationship between Māori and Pākehā to a long-term love affair or marriage with its ups and downs and shot through with relations of power, desire, familiarity and contempt. Relationships ultimately thrive on good communication, and academic discourse is rather like a conversation, punctuated by critique and counter-critique, in collaborative exploration of the edges of knowledge. Therefore I applaud Jenkin (2017) for seeking to explore biculturalism in early childhood education. I believe biculturalism still offers much that can enrich practice and theory of education in Aotearoa-New Zealand, and that this is a worthy topic for discussion in a journal of teachers' work. 


\section{REFERENCES}

Hoskins, T. K. (2012). A fine risk: Ethics in Kaupapa Māori politics. New Zealand Journal of Education Studies: Te Hautaka Mātai Mātauranga, 47(2), 85-99.

Hoskins, T. K., \& Jones, A. (Eds.). (2017). Critical conversations in Kaupapa Māori. Wellington, New Zealand: Huia Publishers.

Jenkin, C. (2017). Early childhood education and biculturalism: Definitions and implications. New Zealand Journal of Teachers' Work, 14(1), 8-20. doi: https://doi.org/10.24135/teacherswork.v14i1.100

Locke, T. (2004). Critical Discourse Analysis. London, United Kingdom/New York, NY: Continuum.

Ministry of Education. (1998). Quality in action - Te mahi whai hua: Implementing the revised statement of desirable objectives and practices in New Zealand early childhood services. Wellington, New Zealand: Learning Media.

Olssen, M., Codd, J., \& O'Neill, A.-M. (2005). Education policy : globalization, citizenship and democracy. London, United Kingdom: Sage.

Stewart, G. (2018). From both sides of the indigenous-settler hyphen in Aotearoa New Zealand. Educational Philosophy and Theory, 50(8), 767775. doi:10.1080/00131857.2016.1204904

Stewart, G. (2017a). The 'hau' of research: Mauss meets Kaupapa Māori. Journal of World Philosophies, 2(1), 1-11. doi:10.2979/jourworlphil.2.1.01

Stewart, G. (2017b). Kaupapa Māori theory as a philosophy for education. In T. K. Hoskins \& A. Jones (Eds.), Critical conversations in Kaupapa Māori (pp. 133-146). Wellington, New Zealand: Huia Publishers.

Stewart, G. (2017c). Mana Wahine and Washday at the Pā. Educational Philosophy and Theory, 1-9. doi:10.1080/00131857.2017.1339339

Stewart, G., \& Dale, H. (2016). 'Dirty laundry' in Māori education history? Another spin for Washday at the Pā. Waikato Journal of Education, 21(2), 5-15.

The opinions expressed are those of the paper author(s) and not the New Zealand Journal of Teachers' Work. Copyright is held by individual authors but offprints in the published format only may be distributed freely by individuals provided that the source is fully acknowledged. [ISSN-1176-6662] 